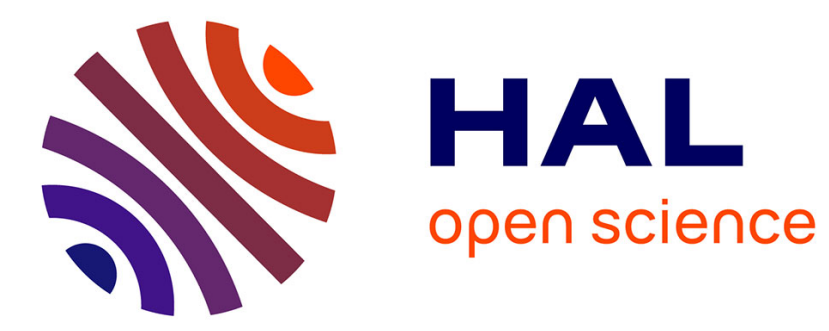

\title{
Systemic lipopolysaccharide influences rectal sensitivity in rats: role of mast cells, cytokines, and vagus nerve
} Anne-Marie Coelho, Jean Fioramonti, Lionel Bueno

\section{To cite this version:}

Anne-Marie Coelho, Jean Fioramonti, Lionel Bueno. Systemic lipopolysaccharide influences rectal sensitivity in rats: role of mast cells, cytokines, and vagus nerve. AJP - Gastrointestinal and Liver Physiology, 2000, 279 (4), pp.G781-G790. hal-02694515

\section{HAL Id: hal-02694515 https://hal.inrae.fr/hal-02694515}

Submitted on 1 Jun 2020

HAL is a multi-disciplinary open access archive for the deposit and dissemination of scientific research documents, whether they are published or not. The documents may come from teaching and research institutions in France or abroad, or from public or private research centers.
L'archive ouverte pluridisciplinaire HAL, est destinée au dépôt et à la diffusion de documents scientifiques de niveau recherche, publiés ou non, émanant des établissements d'enseignement et de recherche français ou étrangers, des laboratoires publics ou privés. 


\section{Anne-Marie Coelho, Jean Fioramonti and Lionel Buéno}

Am J Physiol Gastrointest Liver Physiol 279:781-790, 2000.

You might find this additional information useful...

This article cites 44 articles, 9 of which you can access free at:

http://ajpgi.physiology.org/cgi/content/full/279/4/G781\#BIBL

This article has been cited by 11 other HighWire hosted articles, the first 5 are:

Pathways involved in gut mucosal barrier dysfunction induced in adult rats by maternal deprivation: corticotrophin-releasing factor and nerve growth factor interplay

F. Barreau, C. Cartier, M. Leveque, L. Ferrier, R. Moriez, V. Laroute, A. Rosztoczy, J.

Fioramonti and L. Bueno

J. Physiol., April 1, 2007; 580 (1): 347-356.

[Abstract] [Full Text] [PDF]

Increased feelings with increased body signals

E. P. M. Vianna, J. Weinstock, D. Elliott, R. Summers and D. Tranel

Soc Cogn Affect Neurosci, June 1, 2006; 1 (1): 37-48.

[Abstract] [Full Text] [PDF]

Endotoxin-Induced Uveitis Causes Long-Term Changes in Trigeminal Subnucleus

Caudalis Neurons

D. A. Bereiter, K. Okamoto, A. Tashiro and H. Hirata

J Neurophysiol, December 1, 2005; 94 (6): 3815-3825.

[Abstract] [Full Text] [PDF]

Lipopolysaccharide-induced changes in mesenteric afferent sensitivity of rat jejunum in vitro: role of prostaglandins

B. Wang, J. Glatzle, M. H. Mueller, M. Kreis, P. Enck and D. Grundy

Am J Physiol Gastrointest Liver Physiol, August 1, 2005; 289 (2): G254-G260.

[Abstract] [Full Text] [PDF]

Small Intestinal Bacterial Overgrowth: A Framework for Understanding Irritable Bowel Syndrome

H. C. Lin

JAMA, August 18, 2004; 292 (7): 852-858.

[Abstract] [Full Text] [PDF]

Medline items on this article's topics can be found at http://highwire.stanford.edu/lists/artbytopic.dtl

on the following topics:

Biochemistry .. Lipopolysaccharides

Physiology .. Mast Cells

Oncology .. Interleukin-1

Veterinary Science .. Vagus Nerve

Physiology .. Nerves

Physiology .. Rats

Updated information and services including high-resolution figures, can be found at:

http://ajpgi.physiology.org/cgi/content/full/279/4/G781

Additional material and information about AJP - Gastrointestinal and Liver Physiology can be found at: http://www.the-aps.org/publications/ajpgi

This information is current as of September 6, 2010 .

AJP - Gastrointestinal and Liver Physiology publishes original articles pertaining to all aspects of research involving normal or abnormal function of the gastrointestinal tract, hepatobiliary system, and pancreas. It is published 12 times a year (monthly) by the American Physiological Society, 9650 Rockville Pike, Bethesda MD 20814-3991. Copyright @ 2000 by the American Physiological Society. ISSN: 0193-1857, ESSN: 1522-1547. Visit our website at http://www.the-aps.org/. 


\title{
Systemic lipopolysaccharide influences rectal sensitivity in rats: role of mast cells, cytokines, and vagus nerve
}

\author{
ANNE-MARIE COELHO, JEAN FIORAMONTI, AND LIONEL BUÉNO \\ Neuro-Gastroenterology and Nutrition Unit, Institut National \\ de la Recherche Agronomique, 31931 Toulouse, France \\ Received 20 September 1999; accepted in final form 17 April 2000
}

\begin{abstract}
Coelho, Anne-Marie, Jean Fioramonti, and Lionel Buéno. Systemic lipopolysaccharide influences rectal sensitivity in rats: role of mast cells, cytokines, and vagus nerve. Am J Physiol Gastrointest Liver Physiol 279: G781-G790, 2000.-Intraperitoneal lipopolysaccharide (LPS) produces somatic hyperalgesia, releases interleukin (IL)-1 $\beta$ and tumor necrosis factor- $\alpha$ (TNF- $\alpha)$, and activates vagal afferents. The aim of this study was to evaluate the effect of peripheral LPS on rectal sensitivity and to specify the mechanisms involved. Abdominal muscle contractions were recorded in conscious rats equipped with intramuscular electrodes. Rectal distension (RD) was performed at various times after LPS or experimental treatments. In controls, RD significantly increased the number of abdominal contractions from a threshold volume of distension of $0.8 \mathrm{ml}$. At the lowest volume $(0.4$ $\mathrm{ml})$, this number was increased after administration of LPS ( 3,9 , and $12 \mathrm{~h}$ later), recombinant human IL-1 $\beta$ (from 3 to $9 \mathrm{~h}$ ), recombinant bovine TNF- $\alpha$ (from 6 to $9 \mathrm{~h}$ ), and BrX537A (from 6 to $12 \mathrm{~h}$ ), a mast cell degranulator. The effect of LPS was reduced by doxantrazole, Lys-D-Pro-Thr, and soluble recombinant TNF receptor. Vagotomy selectively amplified the response to LPS. We conclude that, in vivo, intraperitoneal LPS lowers visceral pain threshold (allodynia) through a mechanism involving mast cell degranulation and IL-1 $\beta$ and TNF- $\alpha$ release and that the vagus nerve may exert a tonic protective role against LPS-induced rectal allodynia.

endotoxins; rectal allodynia; mast cells; interleukin-1 $\beta$; tumor necrosis factor- $\alpha$; subdiaphragmatic vagotomy
\end{abstract}

THE GASTROINTESTINAL TRACT represents one of the body's largest interfaces with the outside environment. It possesses a complex immune system providing its defense against environmental threats including infection by viruses, bacteria, and parasites. Approximately one-third of patients with bacterial gastroenteritis develop chronic abdominal symptoms and signs of sensory changes in the gut (1). This entity, called "postinfectious irritable bowel syndrome" (PI-IBS), accounts for $\sim 30 \%$ of all irritable bowel syndrome (IBS) patients. The major symptoms observed in patients with IBS include disordered colonic motility and acute or chronic abdominal pain. These patients exhibit an exaggerated sigmoid motor response to a variety of stimuli (41) and also have a lowered visceral sensory threshold to pain caused by balloon distension (35).

Address for reprint requests and other correspondence: L. Buéno, INRA, NGN Unit, BP 3, F-31931 Toulouse, France (E-mail: lbueno@toulouse.inra.fr).
Unfortunately, the pathophysiology of visceral hypersensitivity in patients with both IBS and bacterial infection is not precisely known.

Lipopolysaccharide (LPS), also known as endotoxin, is a cell wall Gram-negative bacteria component. It induces a wide array of effects after bacterial infection, including fever (18), sickness behavior (17), and hyperalgesia. Indeed, several studies have shown that an intraperitoneal injection of LPS enhances pain responsiveness to various somatic stimuli (see Refs. 43 and 46). Moreover, LPS-induced alterations in nociception depend on proinflammatory cytokines released from monocytes and macrophages under LPS stimulation such as interleukin (IL)-1, IL-6, and tumor necrosis factor- $\alpha(\mathrm{TNF}-\alpha)$. Indeed, an important role of inflammatory cytokines at the peripheral level has been recently recognized in sensory hypersensitivity (44). For example, cutaneous hyperalgesia can be produced by intraperitoneal injection of IL-1 (22) and TNF- $\alpha$ (42). Moreover, after peripheral administration, LPS-, IL-1$\beta$-, and TNF- $\alpha$-induced hyperalgesia requires vagal integrity because it is blocked by subdiaphragmatic vagotomy $(43,44)$. This result agrees with the observation that brain release of proinflammatory mediators, including cytokines, is mediated in part by vagal afferents (19), even though it does not appear to be the only route for LPS/cytokine-to-brain communication (10).

Kanaan et al. (15) showed that intraplantar injection of endotoxin produces local inflammation and delayed somatic hyperalgesia, mediated locally by IL-1 $\beta$, nerve growth factor (NGF), and $\mathrm{PGE}_{2}(39)$. This hyperalgesic effect starts $1-2 \mathrm{~h}$ after intraplantar endotoxin injection and peaks at $9 \mathrm{~h}$ in rats and $24 \mathrm{~h}$ in mice (16). Similarly, we recently reported (3) that experimental mast cell degranulation in vivo induces a delayed (6$12 \mathrm{~h}$ ) increase in sensitivity (allodynia) to rectal distension in awake rats. Indeed, mast cells are involved in postinfectious (24) and stress-induced (13) hyperalgesia, and their density is altered in functional bowel disorders where, for example, an accumulation of mast cells in the ileum has been demonstrated (45). The anatomic arrangement of mast cells places them in the

The costs of publication of this article were defrayed in part by the payment of page charges. The article must therefore be hereby marked "advertisement" in accordance with 18 U.S.C. Section 1734 solely to indicate this fact. 
first line of defense against injury or infection, particularly for skin, airways, and gastrointestinal tract, sites that interface directly with the external environment. These cells are well suited to initiate an acute inflammatory process and, through interaction with other tissue cells, to continue to maintain or modulate later response.

No studies have investigated the influence of systemic LPS on visceral sensitivity, as was previously established for somatic sensitivity. Consequently, the present study was designed to evaluate whether intraperitoneal administration of endotoxin can initiate visceral allodynia to rectal distension in rats and to determine the role of peripheral IL- $1 \beta$ and TNF- $\alpha$, the involvement of mast cells, and the neuronal (vagus and/or other) pathway in LPS-related allodynia.

\section{MATERIALS AND METHODS}

\section{General Surgical Procedure}

Animal preparation. Male Wistar rats (Harlan, Gannat, France), initially weighing between 200 and $250 \mathrm{~g}$, were surgically prepared for electromyography according to a previously described technique (38). Rats were anesthetized by intraperitoneal injection of acepromazine (Calmivet, Vetoquinol, Lure, France) and ketamine (Imalgene 1000, RhôneMérieux, Lyon, France) at doses of 0.6 and $120 \mathrm{mg} / \mathrm{kg}$, respectively. Three groups of three electrodes of $\mathrm{NiCr}$ wire (60-cm length and 80-mm diameter) were implanted bilaterally in the abdominal external oblique musculature just superior to the inguinal ligament. Electrodes were exteriorized on the back of the neck and protected by a glass tube attached to the skin. Animals were individually housed in polypropylene cages and kept in a temperature-controlled room $\left(21^{\circ} \mathrm{C}\right)$. They were allowed free access to water and food (UAR pellets, Epinay, France). All protocols were approved by the Local Animal Care and Use Committee of Institut National de la Recherche Agronomique.

Electromyographic recording. Electromyographic recordings began five days after surgery. The electrical activity of abdominal striated muscles was recorded with an electroencephalograph machine (Mini VIII, Alvar, Paris, France) using a short time constant $(0.03 \mathrm{~s})$ to remove low-frequency signals $(<3 \mathrm{~Hz})$ and a paper speed of $3.6 \mathrm{~cm} / \mathrm{min}$.

Distension procedure. Rats were placed in plastic tunnels (6-cm diameter and 25-cm length) in which they could not move, escape, or turn around, to prevent damage to the balloon. Rats were exposed to this procedure over 3 days before rectal distension (RD) to minimize stress reactions during experiments. The balloon used for distension was an arterial embolectomy catheter (Fogarty, Edwards Laboratories, Santa Ana, CA). RD was performed by insertion of the balloon (2-mm diameter and 2-cm length) in the rectum, at 1 $\mathrm{cm}$ of the anus, the catheter being fixed at the tail with adhesive tape. The balloon was inflated progressively, in $0.4-\mathrm{ml}$ steps, from 0 to $1.6 \mathrm{ml}$, each step of inflation lasting 5 min. To detect possible leakage, the volume of water introduced into the balloon was checked by complete removal with a syringe at the end of the distension period.

\section{Temperature Recording}

To measure body temperature $\left(\mathrm{T}_{\mathrm{b}}\right)$, a thermistor probe (NTC type, code 10K3A1, Farnell, Villefranche sur Saône, France) was placed in the peritoneal cavity, using a previ- ously described technique (26). $\mathrm{T}_{\mathrm{b}}$ was recorded 5 days after surgery by connecting the thermistor probe to an electronic thermometer developed in our laboratory. It was calibrated to give an initial output of $0 \mathrm{~V}$ at $35^{\circ} \mathrm{C}$ with a sensitivity of $200 \mathrm{mV} /{ }^{\circ} \mathrm{C}$. The temperature was monitored on a potentiometric recorder (L6514, Linseis, Selb, Germany) with a paper speed of $2 \mathrm{~cm} / \mathrm{h}$.

\section{Subdiaphragmatic Vagotomy}

Surgery. Seven days before implantation of abdominal electrodes, abdominal vagotomies were performed as follows. Rats were anesthetized with ketamine and acepromazine (120 and $0.6 \mathrm{mg} / \mathrm{kg}$ ip, respectively). After midline laparotomy, the stomach and lower esophagus were visualized. The stomach was gently retracted beneath the diaphragm to clearly expose the ventral and dorsal trunks of the vagus nerve and covered with saline-moistened sterile gauze. Each vagal trunk was dissected from the esophagus and sectioned. The stomach was then returned to its normal position, and the incision was closed. Sham vagotomies consisted of the same operative procedure except that the vagal trunks were neither tied nor sectioned. Animals were returned to their home cages after the operation and were provided with food and water ad libitum. Normal food intake resumed within $3-5$ days after vagotomy.

Verification procedure. The effectiveness of vagus nerve section was assessed 14 days after vagotomy by the sulfated cholecystokinin (CCK-8S) satiety test. Subdiaphragmatic vagotomy suppresses the blockade of food consumption induced by CCK-8S. Consequently, CCK-8S or saline was injected at the dose of $4 \mu \mathrm{g} / \mathrm{kg}$ ip after $20 \mathrm{~h}$ of food deprivation, and food intake was measured $1 \mathrm{~h}$ after injection.

\section{Histological Mast Cell Counting Method}

Intestinal tissue samples were put in Carnoy's solution immediately after the animals were killed, fixed for $24 \mathrm{~h}$ at room temperature, and then embedded in paraffin blocks using routine techniques. Sections were cut at a thickness of $5 \mathrm{~mm}$ and stained with hemalun-eosin for routine histological analysis or with Alcian blue-Safranin O for identification of intestinal mast cells. Three sections for each sample and each animal were analyzed by light microscopy, and the number of intact mast cells was counted for each section. For each animal, the number of intact mast cells per square millimeter of intestinal tissue was the mean of the values obtained for the three sections.

\section{Chemicals}

LPS (from Escherichia coli, serotype 0111:B4; L3024, lot no. 38H4065) was purchased from Sigma-Aldrich (St. Quentin Fallavier, France) and was dissolved in saline $(\mathrm{NaCl}$ $0.9 \%$ ) at a concentration of $1 \mathrm{mg} / \mathrm{ml}$. BrX-537A (bromolasalocid ethanolate) was kindly supplied by Roche Laboratories (London, UK) and was dissolved in DMSO at a concentration of $2 \mathrm{mg} / \mathrm{ml}$. Doxantrazole was obtained from Wellcome Research Laboratories (lot no. 59C72, Beckenham, UK) and was dissolved in DMSO $(5 \mathrm{mg} / \mathrm{ml})$. Recombinant human IL-1 $\beta$ (rhIL-1 $\beta$ ) and recombinant human dimeric soluble TNF receptor (rhuTNF:Fc molecule p75, linked to the Fc portion of the human IgG1; sTNFR) were kindly provided by Dr. Mickael B. Widmer (Immunex, Seattle, WA). They were dissolved in saline and Tris- $\mathrm{NaCl}, \mathrm{pH} 7.4$, respectively. The construction and production of sTNFR has been previously described (27). Recombinant bovine TNF- $\alpha$ (rboTNF- $\alpha$ ) was kindly provided by Sandoz (Basel, Switzerland) and dis- 
solved in saline at a final concentration of $150 \mu \mathrm{g} / \mathrm{ml}$. The tripeptide H-Lys-D-Pro-Thr-OH was purchased from Bachem AG (H-7230, lot no. 122401, Budendorf, Switzerland) and dissolved in saline at a concentration of $10 \mathrm{mg} / \mathrm{ml}$. In all experiments, intraperitoneal injections of drug or vehicle were given in a volume of $1 \mathrm{ml} / \mathrm{kg}$.

\section{Experimental Protocol}

Effect of LPS and role of mast cells. These studies determined the effects of intraperitoneal injection of LPS on rectal sensitivity and the involvement of mast cells using both pharmacological and histological methods. In a first series of experiments, two groups of rats were used. In the first group $(n=6-8)$, rats were injected intraperitoneally with $\mathrm{BrX}$ $537 \mathrm{~A}$ vehicle (DMSO) and, $48 \mathrm{~h}$ later, received $\mathrm{BrX}-537 \mathrm{~A}$ (mast cell degranulator; $2 \mathrm{mg} / \mathrm{kg}$ ip). RDs were performed before ( $-1 \mathrm{~h}$, control) and 3, 6, 9, 12, and $24 \mathrm{~h}$ after $\mathrm{BrX}-537 \mathrm{~A}$ or vehicle administration. The dose of BrX-537A ( $2 \mathrm{mg} / \mathrm{kg})$ has been found active in a model of rectal sensitivity (3). Eight days later, the same animals were injected intraperitoneally with LPS vehicle (saline) and, $48 \mathrm{~h}$ later, received LPS ( $1 \mathrm{mg} / \mathrm{kg}$ ip). RDs were performed before ( $-1 \mathrm{~h}$, control) and $3,6,9,12$, and $24 \mathrm{~h}$ after LPS or vehicle administration. The dose of LPS was chosen according to preliminary experiments showing less reproducible and significant data at lower doses (i.e., 0.1 and $0.5 \mathrm{mg} / \mathrm{kg}$ ip; Coelho et al., unpublished observations). In the second group $(n=8)$, rats were injected, in a randomized order, with doxantrazole $(5 \mathrm{mg} / \mathrm{kg}$ ip), a mast cell stabilizing agent, or its vehicle $20 \mathrm{~min}$ before LPS or its vehicle. RDs were performed before ( $-1 \mathrm{~h}$, control) and $3,6,9$, and $12 \mathrm{~h}$ after LPS administration. An 8-day interval was observed between two single LPS administrations. The dose of doxantrazole ( $5 \mathrm{mg} / \mathrm{kg}$ ip) was chosen according to its efficacy in preventing mast cell degranulation-induced rectal allodynia (3). The time chosen between two single administrations of LPS (8 days) was judged to be the minimum necessary time for a complete recovery from each LPS treatment to eliminate a tolerance parameter of our LPS treatments.

In a second series of experiments, five groups of eight male Wistar rats weighing 250-300 g were used for histological studies. Group 1 was used as control. Groups 2 and 3 received BrX-537A (2 mg/kg ip). Groups 4 and 5 received LPS ( $1 \mathrm{mg} / \mathrm{kg}$ ip). Rats in groups 2 and 4 were killed $1 \mathrm{~h}$ after administration; those in groups 3 and 5 were killed $5 \mathrm{~h}$ later. Tissue samples of ileum and proximal colon $(2-3 \mathrm{~cm}$ from the cecocolonic junction) were collected and prepared for mast cell counting.

Effect of LPS on $T_{b}$ and behavior. $\mathrm{T}_{\mathrm{b}}$ was recorded in a group of five rats. On day 1, animals were injected intraperitoneally with vehicle (saline, $1 \mathrm{ml} / \mathrm{kg}$ ) after $1 \mathrm{~h}$ of temperature control recording. Temperature was monitored for a period of $24 \mathrm{~h}$ to establish a baseline. On day 2 , the same animals were injected intraperitoneally with LPS $(1 \mathrm{mg} / \mathrm{kg})$ and $T_{b}$ was recorded for $24 \mathrm{~h}$. All measurements were performed at a subthermoneutral ambient temperature of $21.0 \pm 1.0^{\circ} \mathrm{C}$. All animals received saline or LPS between 8:30 and 9:00 AM.

Role of IL-1 $\beta$. Two groups of rats were used to evaluate the role of IL-1 $\beta$. Group $1(n=9)$ was given rhIL-1 $\beta$ at a dose (10 $\mu \mathrm{g} / \mathrm{kg}$ ip) known to induce sickness behavior (44). Vehicle was injected intraperitoneally for control purposes. RDs were performed $3,6,9$, and $12 \mathrm{~h}$ after rhIL- $1 \beta$ or vehicle administration. Group $2(n=5)$ received, in a randomized order, intraperitoneal injection of tripeptide Lys-D-Pro-Thr (or vehicle) $30 \mathrm{~min}$ before LPS injection, at the dose $(10 \mathrm{mg} / \mathrm{kg})$ known to antagonize IL-1 $\beta$-induced hyperalgesia (7) and to significantly reduce the hyperalgesic effect of intraplantar LPS (39). The same group received an injection of tripeptide alone. RDs were performed before $(-1 \mathrm{~h}$, control) and $12 \mathrm{~h}$ after LPS (or vehicle) injection. Eight days separated LPS/ vehicle and LPS/tripeptide randomized treatments.

Role of TNF- $\alpha$. Two groups of rats were used. Group $1(n=$ 6) was injected intraperitoneally with rboTNF- $\alpha$, or its vehicle, at a dose $(150 \mu \mathrm{g} / \mathrm{kg})$ found to be active in a model of somatic hyperalgesia (42). RDs were performed $3,6,9$, and $12 \mathrm{~h}$ later. Group $2(n=6)$ was injected twice intraperitoneally with sTNFR (total dose $2 \mathrm{mg} / \mathrm{kg}$ ) or vehicle; the first injection $(1 \mathrm{mg} / \mathrm{kg}$ ) was performed immediately before LPS (1 $\mathrm{mg} / \mathrm{kg}$ ip) or saline, and the second injection $(1 \mathrm{mg} / \mathrm{kg})$ was performed 90 min later. RDs were performed before $(-1 \mathrm{~h}$, control) and $12 \mathrm{~h}$ after LPS or saline injection. The delay of 90 min for the second injection was chosen according to the efficacy of sTNFR, a procedure previously validated in mice (27). Eight days separated LPS/vehicle and LPS/sTNFR randomized treatments.

Effect of subdiaphragmatic vagotomy on LPS effect. Four groups of rats were used to determine the role of vagal nerves: sham vagotomy + vehicle $(n=5)$, sham vagotomy + LPS $(n=8)$, vagotomy + vehicle $(n=7)$, and vagotomy + LPS $(n=7)$. Rats were injected intraperitoneally with LPS (1 $\mathrm{mg} / \mathrm{kg}$ ) or its vehicle. RD was performed $12 \mathrm{~h}$ after vehicle or LPS injection.

\section{Statistical Analysis}

Statistical analysis of the number of abdominal contractions for each 5-min period during RD was performed by one-way ANOVA followed by Student's unpaired or paired $t$-test where relevant. Values are expressed as means $\pm \mathrm{SE}$. $\mathrm{T}_{\mathrm{b}}$ values are presented as means $\pm \mathrm{SE}$ and were compared by one-way ANOVA followed by Student's paired $t$-test. Mast cell numbers per square millimeter were analyzed using the Mann-Whitney $U$-test for unpaired data, and values are expressed as means \pm SE. All differences were considered significant at $P<0.05$.

\section{RESULTS}

\section{Effect of Intraperitoneal Injection of LPS on Rectal Sensitivity}

Gradual RD increased the frequency of abdominal contractions in a distension volume-dependent manner. A volume of $0.8 \mathrm{ml}$ was determined as the threshold at which RD induced a significant increase of the number of abdominal contractions compared with the predistension level (29). Saline-treated rats and untreated controls responded similarly to RD regardless of volume (0-1.6 ml) and time of distension (3, 6, 9, 12, and $24 \mathrm{~h})$. LPS ( $1 \mathrm{mg} / \mathrm{kg}$ ip) increased the number of abdominal contractions for the $0.4-\mathrm{ml}$ volume $3(11.0 \pm$ 1.8 contractions $/ 5 \mathrm{~min}), 9(10.5 \pm 2.5$ contractions $/ 5$ $\mathrm{min})$, and $12(16.1 \pm 3.0$ contractions $/ 5 \mathrm{~min}) \mathrm{h}$ after its administration compared with $3.4 \pm 0.9$ contractions $/ 5$ min for the control RD performed $1 \mathrm{~h}$ before LPS (Fig. 1 ). At other times (6 and $24 \mathrm{~h}$ ) and other volumes $(0.8-1.6 \mathrm{ml})$, abdominal responses were unaffected $(P>0.05)$ by LPS treatment (data not shown). On the basis of these data, we used the time of $12 \mathrm{~h}$ (maximal effect) to perform RDs in subsequent pharmacological 


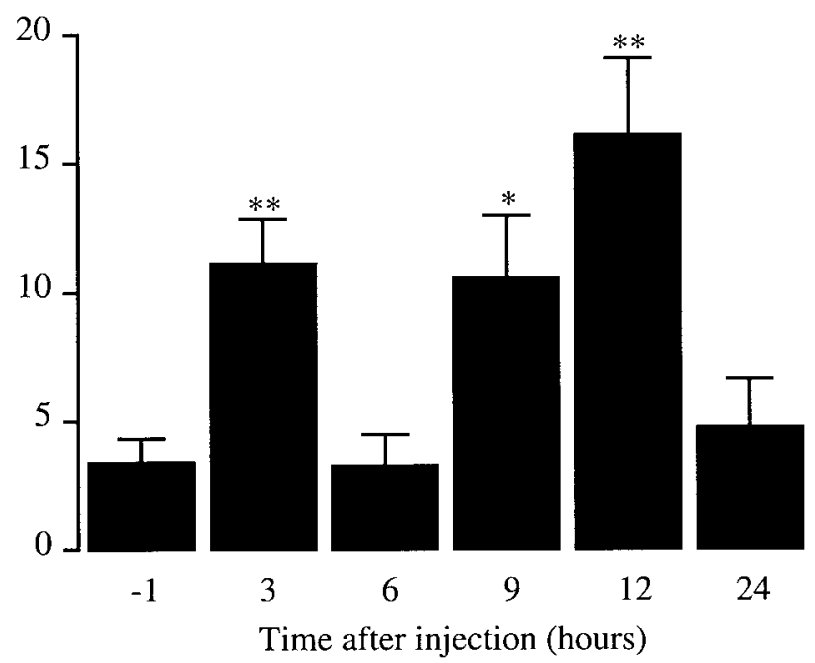

B

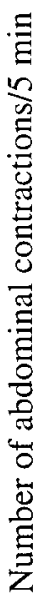

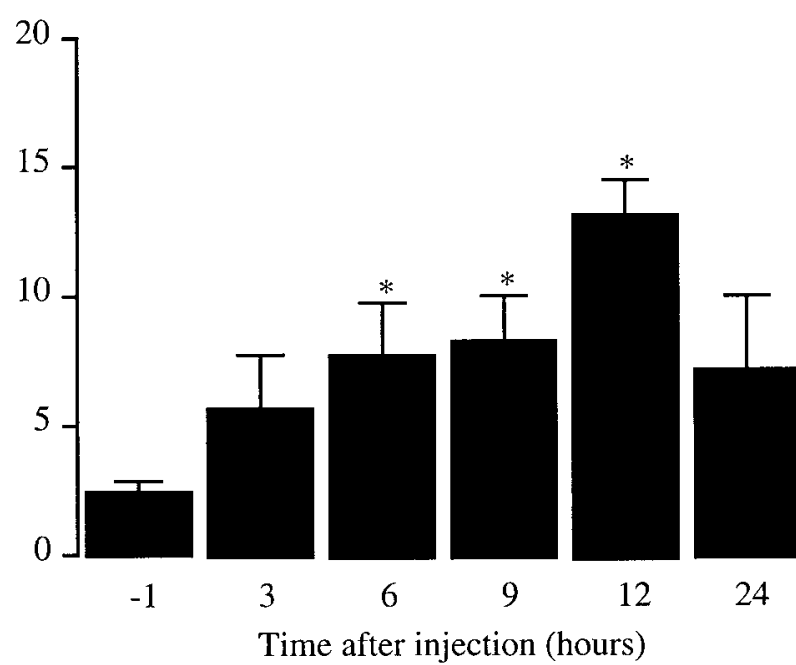

Fig. 1. Kinetics of lipopolysaccharide (LPS; $A$ ) and BrX-537A (B) effects on abdominal responses to rectal distension at the $0.4-\mathrm{ml}$ volume in awake rats. Both LPS (1 mg/kg ip) and BrX-537A $(2 \mathrm{mg} / \mathrm{kg}$ ip) increased the number of abdominal contractions elicited by the lowest volume of distension at 3,9 , and $12 \mathrm{~h}$ and 6,9 , and $12 \mathrm{~h}$ after injections, respectively. Values are means $\pm \mathrm{SE} ; n=6-8$ rats. Significant difference from control value measured $1 \mathrm{~h}$ before injections: $* P<0.05, * * P<0.01$.

investigations except for kinetic studies and determination of mast cell involvement.

\section{Effect of Intraperitoneal Injection of LPS on $T_{b}$ and Behavior}

The basal core temperature of rats was $37.8 \pm 0.2^{\circ} \mathrm{C}$. Intraperitoneal injection of vehicle (saline, $1 \mathrm{ml} / \mathrm{kg}$ ) did not significantly $(P>0.05)$ modify the profile of $\mathrm{T}_{\mathrm{b}}$ during the daytime period of recording. All rats displayed normal circadian changes in $\mathrm{T}_{\mathrm{b}}$, with lower daytime and higher nighttime $\mathrm{T}_{\mathrm{b}}$ values (data not shown). LPS (1 mg/kg ip) significantly increased $(P<$
0.05) $\mathrm{T}_{\mathrm{b}}$ between 1.5 and $9 \mathrm{~h}$ after injection. The $\mathrm{T}_{\mathrm{b}}$ increase was characterized by the occurrence of two peak elevations, a first maximal $\mathrm{T}_{\mathrm{b}}$ rise that peaked $2 \mathrm{~h}$ later $\left(38.5 \pm 0.2 \mathrm{vs} .37 .5 \pm 0.1^{\circ} \mathrm{C}\right.$ of vehicle control) and a second maximal $\mathrm{T}_{\mathrm{b}}$ rise that appeared $5.5 \mathrm{~h}$ later $\left(38.4 \pm 0.2\right.$ vs. $37.2 \pm 0.1^{\circ} \mathrm{C}$ ) (Fig. 2). Between 10 and $24 \mathrm{~h}$, there were no differences in $\mathrm{T}_{\mathrm{b}}$ between vehicle and LPS treatments. Concerning behavioral effects, rats injected with $1 \mathrm{mg} / \mathrm{kg}$ LPS showed a few signs of illness such as piloerection and lack of activity, but these did not last longer than $24 \mathrm{~h}$. At the high dose used, no deaths were noted.

\section{Involvement of Mast Cells in LPS-Induced Rectal Hypersensitivity}

As previously described (3), the number of abdominal contractions observed at the lowest volume of distension $(0.4 \mathrm{ml})$ was significantly increased 6,9 , and $12 \mathrm{~h}$ after BrX-537A ( $2 \mathrm{mg} / \mathrm{kg}$ ip; $7.7 \pm 2.0,8.2 \pm 1.8$, and $13.1 \pm 1.4$ contractions $/ 5 \mathrm{~min}$, respectively, vs. $2.4 \pm$ 0.5 for control RD) (Fig. 1). Doxantrazole ( $5 \mathrm{mg} / \mathrm{kg}$ ip) or its vehicle was given $20 \mathrm{~min}$ before LPS, and RD were performed 3, 6, 9, and $12 \mathrm{~h}$ after LPS. As in the previous series of experiments, animals receiving LPS after vehicle treatment showed an increase in the number of abdominal contractions only for the threshold volume of $0.4 \mathrm{ml}$ at 3,9 , and $12 \mathrm{~h}$ after LPS (Fig. 3). Prior administration of doxantrazole ( $5 \mathrm{mg} / \mathrm{kg}$ ip) suppressed the abdominal response observed 3-12 $\mathrm{h}$ after LPS; compared with vehicle, doxantrazole significantly $(P<0.05)$ decreased the number of abdominal contractions at the $0.4-\mathrm{ml}$ volume of distension, $3(3.7 \pm 1.7 \mathrm{vs}$. $11.0 \pm 1.8$ contractions $/ 5$ min for LPS + vehicle control $)$ and $12(5.7 \pm 2.2$ vs $16.1 \pm 3.0) \mathrm{h}$ after LPS administration (Fig. 3).

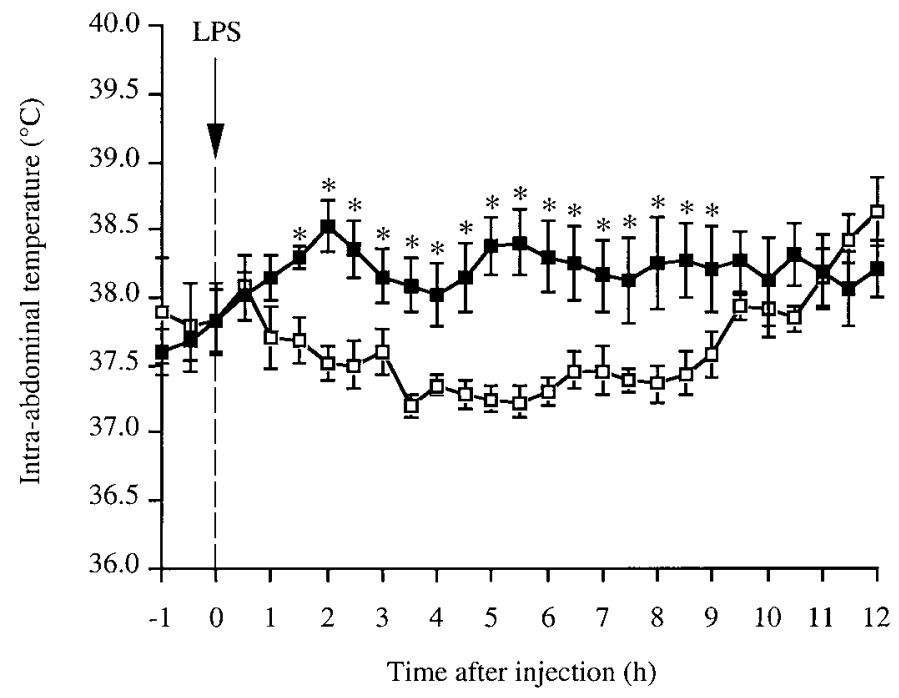

$\longrightarrow$ Vehicle $(1 \mathrm{ml} / \mathrm{kg} \mathrm{iP})$

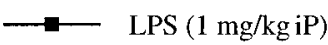

Fig. 2. Effect of LPS on body temperature. LPS ( $1 \mathrm{mg} / \mathrm{kg}$ ip) induced a biphasic fever with 2 maximal peritoneal temperature rises, 2 and $5-6 \mathrm{~h}$ after injection, respectively. Values are means $\pm \mathrm{SE} ; n=5$ rats. ${ }^{*}$ Significant difference $(P<0.05)$ from corresponding vehicle values. 


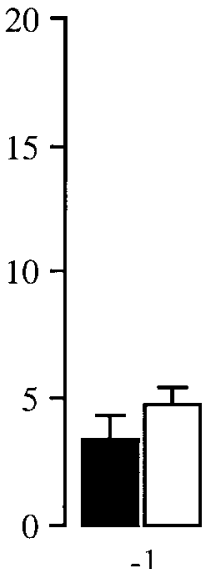

$-1$

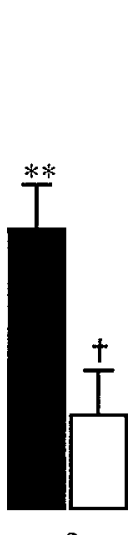

3

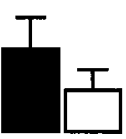

6

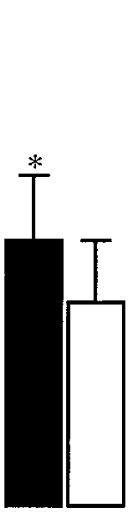

9

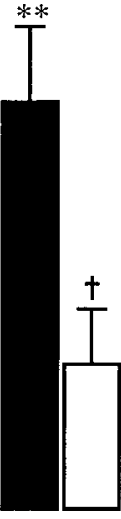

12
Time after injection (hours)

LPS $(1 \mathrm{mg} / \mathrm{kg} \mathrm{iP})+$ vehicle $(1 \mathrm{ml} / \mathrm{kg} \mathrm{iP})$

LPS ( $1 \mathrm{mg} / \mathrm{kg}$ iP) + Doxantrazole ( $5 \mathrm{mg} / \mathrm{kg}$ iP)

Fig. 3. Effect of the mast cell stabilizer doxantrazole on LPS-induced increase of abdominal contractions in response to rectal distension $(0.4 \mathrm{ml})$. Doxantrazole $(5 \mathrm{mg} / \mathrm{kg}$ ip) reduced the increase in the number of abdominal contractions induced by LPS 3 and $12 \mathrm{~h}$ after injection. Values are means $\pm \mathrm{SE} ; n=8$ rats. Significant difference from the control value $(-1 \mathrm{~h}): * P<0.05, * * P<0.01$. †Significant difference $(P<0.05)$ from corresponding LPS + vehicle value.

\section{Mast Cell Numbers After LPS Administration}

To confirm the involvement of mast cells in LPSinduced visceral hypersensitivity and to compare the time course of mast cell degranulation with BrX-537A, histological examination of mucosal mast cells in the ileum and proximal colon was performed on rats treated with either BrX-537A or LPS. The number of intact mucosal mast cells in control animals was $215.1 \pm 33.1$ and $133.0 \pm 17.9$ cells $/ \mathrm{mm}^{2}$ in the ileum and proximal colon, respectively. When rats were injected with $\mathrm{BrX}-537 \mathrm{~A}$ ( $2 \mathrm{mg} / \mathrm{kg}$ ip), this number was significantly reduced $(107.2 \pm 17.6$ and $81.2 \pm 38.9$ cells $\left./ \mathrm{mm}^{2} ; P<0.05\right) 1 \mathrm{~h}$ after BrK-537A administration. In contrast, rats given LPS presented a lower number of intact mucosal mast cells only $5 \mathrm{~h}(131.0 \pm$ 22.3 and $72.8 \pm 23.7$ cells $/ \mathrm{mm}^{2}$ ) after LPS administration (Table 1).
Table 2. Kinetics of rhIL-1 $\beta$ and rboTNF- $\alpha$ effects on abdominal response to gradual distension in awake rats

\begin{tabular}{lcccc}
\hline \hline & $3 \mathrm{~h}$ & $6 \mathrm{~h}$ & $9 \mathrm{~h}$ & $12 \mathrm{~h}$ \\
\hline Vehicle $(0.3 \mathrm{ml} / \mathrm{rat})$ & $3.9 \pm 1.2$ & $4.2 \pm 1.0$ & $6.9 \pm 1.5$ & $7.2 \pm 2.0$ \\
rhIL-1 $(10 \mu \mathrm{g} / \mathrm{kg} \mathrm{ip})$ & $14.0 \pm 3.0^{*}$ & $11.9 \pm 3.1^{*}$ & $14.1 \pm 2.2^{*}$ & $9.6 \pm 2.2$ \\
Vehicle $(0.3 \mathrm{ml} / \mathrm{rat})$ & $3.7 \pm 2.2$ & $3.5 \pm 2.6$ & $4.8 \pm 3.4$ & $5.5 \pm 2.5$ \\
rboTNF- $\alpha$ & & & & \\
$\quad(150 \mu \mathrm{g} / \mathrm{kg} \mathrm{ip})$ & $12.3 \pm 5.7$ & $19.0 \pm 2.0 \dagger$ & $16.8 \pm 2.9 *$ & $7.0 \pm 4.5$ \\
\hline
\end{tabular}

Values are means $\pm \mathrm{SE}$ of the number of abdominal contractions during 5-min periods at the $0.4-\mathrm{ml}$ volume of distension; $n=6-8$ rats. Recombinant human interleukin-1 $\beta$ (rhIL-1 $\beta$ ) and recombinant bovine tumor necrosis factor- $\alpha$ (rboTNF- $\alpha$ ) increased the number of abdominal contractions elicited at the $0.4-\mathrm{ml}$ volume of distension from 3 to $9 \mathrm{~h}$ and from 6 to $9 \mathrm{~h}$ after injections, respectively. $* P<$ $0.05, \dagger P<0.001$ significantly different from corresponding vehicle values.

\section{Involvement of IL-1 $\beta$ in LPS-Induced Delayed Visceral Allodynia}

After intraperitoneal injection of rhIL-1 $\beta(10 \mu \mathrm{g} / \mathrm{kg})$, a significant $(P<0.05)$ increase of the number of abdominal contractions generated by the $0.4-\mathrm{ml}$ volume of distension, compared with vehicle, was observed 3,6 , and $9 \mathrm{~h}$ after rhIL-1 $\beta$ administration (Table 2). No significant increase of abdominal contractions was observed after intraperitoneal injection of saline for the same volume of distension, compared with baseline contractions, at any time of RD after saline. The tripeptide Lys-D-Pro-Thr (10 mg/kg ip) did not affect per se the abdominal response induced by $\mathrm{RD}$ at any volume of distension applied. However, when injected $30 \mathrm{~min}$ before LPS ( $1 \mathrm{mg} / \mathrm{kg}$ ip), the tripeptide significantly decreased $(P<0.05)$ the number of abdominal contractions at the distension volume of $0.4 \mathrm{ml}$ (Fig. $4, A$ and $B) 12 \mathrm{~h}$ after LPS (7.2 \pm 2.0 vs. $15.8 \pm 3.7$ for LPS + vehicle control).

\section{Involvement of TNF- $\alpha$ in LPS-Induced Delayed Visceral Allodynia}

Similarly to rhIL-1 $\beta$, systemic administration of rboTNF- $\alpha(150 \mu \mathrm{g} / \mathrm{kg}$ ip) regenerated rectal allodynia; intraperitoneal administration of rboTNF- $\alpha$ increased the number of abdominal contractions induced by RD at the $0.4-\mathrm{ml}$ volume by $67 \%$ and $58 \%$ at 6 and $9 \mathrm{~h}$ after administration, respectively, compared with control animals treated with vehicle (Table 2). sTNFR (2 $\mathrm{mg} / \mathrm{kg}$ ip) had no effect per se on basal rectal sensitiv-

Table 1. Number of intact mast cells identified in ileum and proximal colon 1 and $5 \mathrm{~h}$ after BrX-537A or LPS administration

\begin{tabular}{lcrrr}
\hline \hline & & \multicolumn{2}{c}{ BrX-537A $(2 \mathrm{mg} / \mathrm{kg} \mathrm{ip})$} & \multicolumn{2}{c}{ LPS $(1 \mathrm{mg} / \mathrm{kg}$ ip $)$} \\
\cline { 3 - 4 } & Control & $+1 \mathrm{~h}$ & $+5 \mathrm{~h}$ & $+1 \mathrm{~h}$ \\
\hline Ileum & $215.1 \pm 33.1$ & $107.2 \pm 7.2 \dagger$ & $155.3 \pm 9.4$ & $204.2 \pm 23.9$ \\
\hline
\end{tabular}

Values (no. of intact mast cells $/ \mathrm{mm}^{2}$ ) are means $\pm \mathrm{SE} ; n=6-8$ rats. LPS, lipopolysaccharide. ${ }^{*} P<0.05, \dagger P<0.01$ significantly different from corresponding control values. 
Fig. 4. Effect of tripeptide Lys-D-ProThr on LPS-induced increase of number of abdominal contractions in response to rectal distension at different volumes of distension $(A)$ and at the lowest volume of distension $(0.4 \mathrm{ml} ; B)$. Lys-DPro-Thr (10 mg/kg ip) significantly reduced the number of abdominal contractions at the $0.4-\mathrm{ml}$ volume of distension $12 \mathrm{~h}$ after LPS administration. Values are means $\pm \mathrm{SE} ; n=5$ rats. **Significant difference $(P<0.01)$ from corresponding control values. $\dagger$ Significant difference $(P<0.05)$ from corresponding LPS + vehicle value.
$\mathbf{A}$

हี

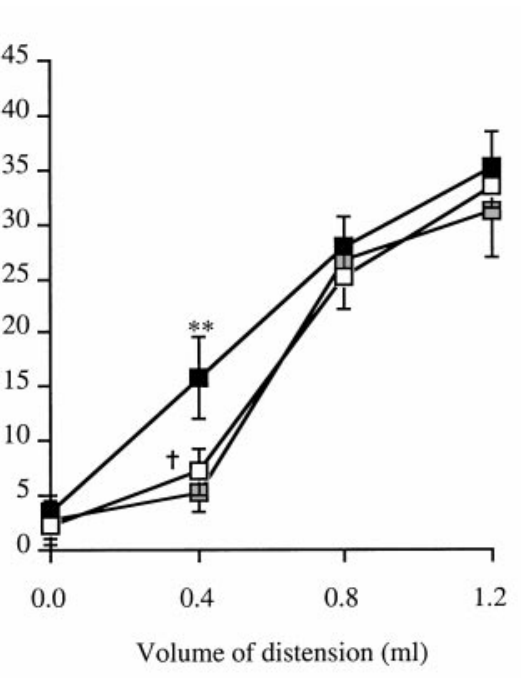

Control rectal distension
B

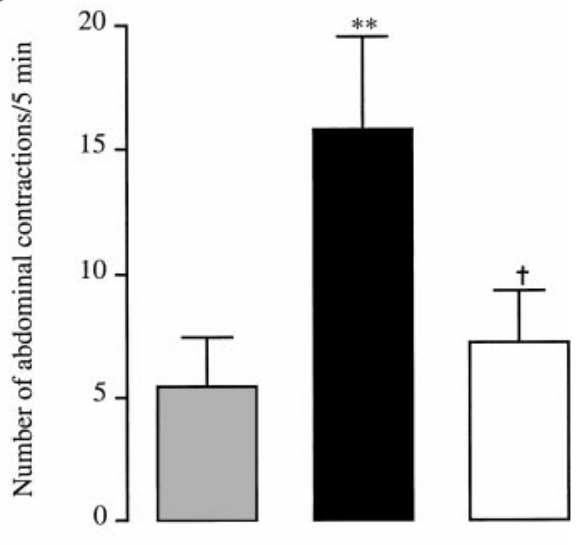

Volume of distension: $0.4 \mathrm{ml}$
LPS $(1 \mathrm{mg} / \mathrm{kg}$ ip ) +

Lys-D-Pro-Thr $(10 \mathrm{mg} / \mathrm{kg}$ ip) ity, but, when injected before LPS, sTNFR significantly $(P<0.05)$ reduced the LPS-induced increase in the number of abdominal contractions observed at the 0.4 -ml volume (Fig. 5, $A$ and $B$ ) $12 \mathrm{~h}$ after LPS administration $(4.7 \pm 0.9$ vs. $15.5 \pm 2.1$ contractions $/ 5 \mathrm{~min}$ for LPS + vehicle control).

\section{Involvement of Vagus Nerves in LPS-Induced Delayed Visceral Allodynia}

CCK-8S significantly $(P<0.05)$ inhibited food intake in sham-vagotomized but not in vagotomized animals, thereby confirming the role of the vagus nerve in the CCK satiety test. Food intake was significantly decreased in CCK-injected sham-vagotomized rats compared with saline control sham-operated animals $(1.8 \pm 0.5$ vs. $4.5 \pm 0.4 \mathrm{~g})$, whereas CCK-8S did not modify food intake in vagotomized animals compared with corresponding saline-injected vagotomized animals $(3.7 \pm 0.7$ vs. $4.4 \pm 0.4 \mathrm{~g})$.

After vehicle treatment, subdiaphragmatic truncal vagotomy did not affect the number of abdominal contractions compared with sham-vagotomized animals at any volume of RD (Fig. 6). In sham-vagotomized animals, LPS increased the number of abdominal contractions $12 \mathrm{~h}$ after its administration at the RD volume of $0.4 \mathrm{ml}(14.7 \pm 1.4$ vs. $4.9 \pm 2.3$ abdominal contractions/5 min for vehicle control), similarly to what was observed in intact animals. Surprisingly, marked differences occurred between sham-vagotomized and vagotomized groups after LPS injection (Fig. 6): the number of abdominal contractions at the lowest volume of distension $(0.4 \mathrm{ml})$ reached $23.9 \pm 4.4$ contractions $/ 5$ min in vagotomized animals, a value significantly higher than that observed in sham-vagotomized ani-
Fig. 5. Effect of peripheral administration of soluble tumor necrosis factor receptor (sTNFR) on LPS-induced increase of number of abdominal contractions in response to rectal distension in awake rats at different volumes of distension $(A)$ and at the lowest volume of distension $(0.4 \mathrm{ml} ; B)$. Note that sTNFR $(2$ $\mathrm{mg} / \mathrm{kg}$ ip) significantly reduced the number of abdominal contractions elicited by LPS injection only at the volume of 0.4 $\mathrm{ml} 12 \mathrm{~h}$ after LPS. Values are means \pm $\mathrm{SE} ; n=6$ rats. *Significant difference $(P<0.05)$ from corresponding control values. † Significant difference $(P<$ 0.01 ) from LPS + vehicle-treated animals.

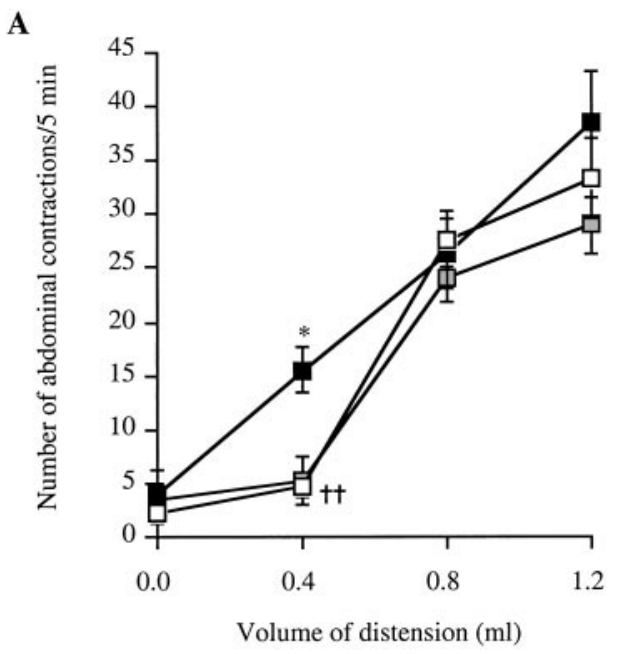

B

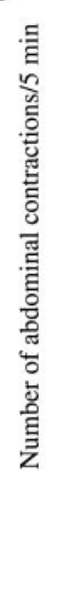

Control rectal distension

LPS (1 mg/kg ip) + Vehicle (1 ml/kg ip)
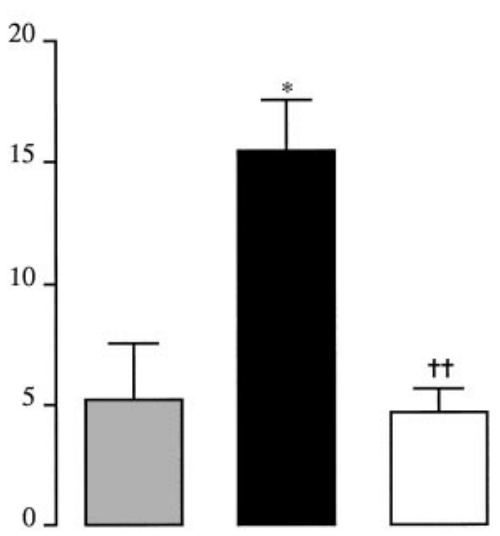

Volume of distension: $0.4 \mathrm{ml}$

LPS $(1 \mathrm{mg} / \mathrm{kg}$ ip $)+$ sTNFR ( $2 \mathrm{mg} / \mathrm{kg}$ ip) 


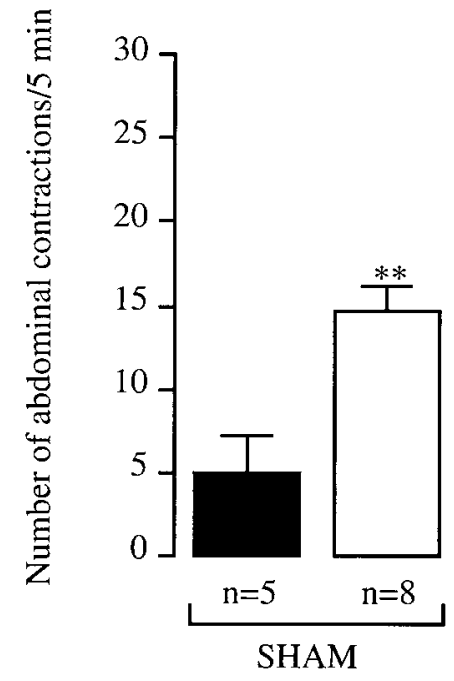

Vehicle $(1 \mathrm{ml} / \mathrm{kg}$ ip $)$

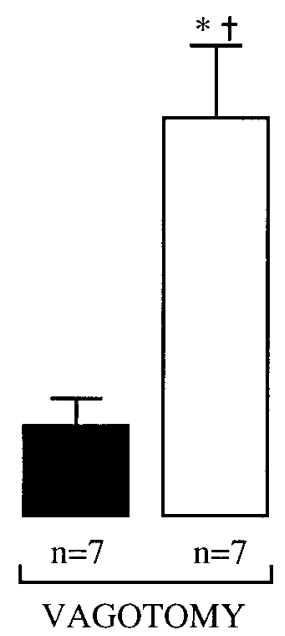

LPS ( $1 \mathrm{mg} / \mathrm{kg}$ ip)

Fig. 6. Influence of vagotomy vs. sham operation on LPS-induced delayed $(12 \mathrm{~h})$ rectal hypersensitivity to distension. The response to LPS is amplified in vagotomized animals. Values are means $\pm \mathrm{SE} ; n$, no. of rats. Significant difference from corresponding vehicle control value: $* P<0.05, * * P<0.01$. $†$ Significant difference $(P<0.05)$ from corresponding sham + LPS value.

mals $(14.7 \pm 1.4$ contractions $/ 5$ min for sham + LPS value).

\section{DISCUSSION}

The present experiments provide new insights regarding the effects of LPS on visceral sensitivity as previously investigated for somatic pain $(43,46)$. First, intraperitoneal injection of LPS triggers a delayed lowering $(9-12 \mathrm{~h})$ of the threshold of rectal distensioninduced nociception in rats. Second, among the various proinflammatory mediators released in response to LPS, IL- $1 \beta$ and TNF- $\alpha$ appear to have a critical role in the genesis of LPS-induced rectal allodynia. Third, the nociceptive response observed after LPS administration is attenuated by doxantrazole, a mast cell stabilizer, and histological studies confirmed gut mucosal mast cell degranulation after LPS injection. Fourth, subdiaphragmatic vagotomy, surprisingly, increases the magnitude of rectal allodynia induced by LPS. Together, these data lead to the conclusion that intraperitoneal LPS evokes a mast cell- and cytokine-dependent delayed rectal allodynia controlled by vagus nerves.

In the first part of the study, we demonstrated that intraperitoneal LPS decreases rectal pain threshold but does not modify the magnitude of response to noxious volumes of distension. These data suggest that LPS released during infection favors an abnormal visceral sensitivity to mechanical stimuli, corresponding to a lowered threshold of barosensitivity, without affecting the visceral pain intensity evoked by noxious stimulation. The same observations were described previously after inflammation of colorectal mucosa by

trinitrobenzene sulfonic acid in ethanol (29). The mechanisms evoking such abnormal visceral sensitivity are not yet fully understood. Such abnormal pain sensation, known as allodynia, could be related to a sensitization of low-threshold primary afferents, known to transmit nonpainful sensations in normal conditions and to be able to trigger postsynaptic nociceptive messages in inflammatory conditions. Such alterations have already been observed after nerve injury and cutaneous inflammation in somatic sensitivity $(2,12$, 21). In the present study, the absence of change in the abdominal response for higher volumes may be related to the lack of sensitization of high-threshold afferents during the $12 \mathrm{~h}$ after LPS administration. Such a hypothesis might explain why LPS turns rectal perception into an abnormal one (allodynia) without modifying the pain response magnitude evoked by noxious stimuli.

We have also observed that intraperitoneal LPS enhances rectal sensitivity in two distinct periods, i.e., $3 \mathrm{~h}$ (early phase) and from 9 to $12 \mathrm{~h}$ (late phase) after its administration. We can attribute the early phase to a direct effect of endotoxin or pronociceptive mediators, such as $\mathrm{PGE}_{2}$ released from macrophages, acting on primary afferent terminals and the late phase to the subsequent development of inflammation with an intense activation of primary afferent fibers and changes in spinal or central processing $(25,32)$. In agreement with such a hypothesis, most reports related to endotoxin-induced somatic hyperalgesia have measured a decrease in the latency to cutaneous nociceptive stimulus that occurred in the first hour after intraperitoneal injection of LPS $(44,46)$. In addition, a model of localized inflammatory hyperalgesia was recently developed in rats using intraplantar injection of endotoxin in the hind paw (15). In this study, Kanaan et al. (15) also observed a peak of hyperalgesia $9 \mathrm{~h}$ after endotoxin injection with complete recovery $24 \mathrm{~h}$ later, and they explained this delayed response by a similar time-related occurrence of a localized inflammatory reaction.

Different patterns of body temperature profile (monophasic fever, biphasic fever, and hypothermia/ hyperthermia) have been described depending on the dose of LPS used (36). At a high dose ( $\geq 1 \mathrm{mg} / \mathrm{kg})$, LPS triggers first a 1- to 3-h decrease of body temperature (hypothermia) followed by a long $(6-24 \mathrm{~h})$ period of fever $(37,47)$. In the present experiments, intraperitoneal administration of a high dose of LPS, i.e., $1 \mathrm{mg} / \mathrm{kg}$, evokes a biphasic fever with two peaks of hyperthermia 2 and 5-6 h later, but we have never observed an initial hypothermia in the first hour after injection. Such a discrepancy may be related to LPS preparation or serotype, rat strain, or route of administration, as previously reported $(11,15)$.

In the third part of the study, we showed that LPSinduced delayed allodynia is attenuated by an IL-1 $\beta$ receptor antagonist, the tripeptide Lys-D-Pro-Thr. This result agrees with previous observations in which LPSinduced somatic hyperalgesia was also abolished by intraperitoneal administration of the IL-1 receptor an- 
tagonist (22) and by this tripeptide (39). Moreover, Kanaan et al. (15) also suggested the involvement of IL-1 $\beta$ in the mediation of both endotoxin-induced thermal and mechanical hyperalgesia. Moreover, intraperitoneal IL-1 $\beta$ reproduces the nociceptive response of LPS on the pain threshold to rectal distension with a time course of 3-9 h. Similarly, sTNFR, which acts as a functional TNF antagonist, reduces LPS-induced delayed allodynia (12 h), suggesting that TNF- $\alpha$ participates in the delayed decrease of rectal pain threshold after LPS. These results are also in agreement with data obtained for somatic pain. Indeed, the cutaneous hyperalgesic effect of LPS can be blocked by TNF- $\alpha$ binding protein, which acts as a functional TNF antagonist $(42,44)$. Intraperitoneal TNF- $\alpha$ administration can also reproduce LPS nociceptive response with a delayed maximal response appearing between 6 and 9 h. A long-lasting somatic hyperalgesia after intraplantar TNF- $\alpha$ administration has also been reported (4).

Changes in visceral sensitivity related to LPS could be secondary to the activation of chemosensitive nociceptors by inflammatory and/or proalgesic mediators (32). Several chemicals produced by local cells are capable of changing the sensitivity of nociceptors, including bradykinin, histamine, 5-hydroxytryptamine, neuropeptides such as substance $\mathrm{P}$ and calcitonin gene-related peptide, prostaglandins (5), and also cytokines $(4,7)$. LPS stimulates the expression of a large number of cytokines, particularly IL- $1 \beta$ and TNF- $\alpha$, that may act directly on receptors found on neurons or indirectly by stimulating the release of proalgesic substances that can act on neurons in a cascadelike manner (40). For example, IL-1, as well as LPS, stimulates the arachidonic acid cascade, resulting in prostanoid production and release (28) that sensitize primary afferent nociceptors and augment the excitability of sensory afferents (5). However, other mediators such as bradykinin can initiate both the cascade of cytokine release that mediates hyperalgesic response to endotoxins (9) and activation and sensitization of pain nociceptors (14). In contrast to these data, IL-1 can also induce hyperalgesia by acting directly on high-threshold mechanoreceptors, leading to a decrease in latency of neuronal discharges, to a lowering of the threshold, and to an increase of neuronal response to mechanical and thermal stimulation (10). In fact, these observations suggest a dual action of IL-1 $\beta$ on different structures such as immune cells and the endings of terminal neurons, depending on the pathophysiological context. Concerning the potential involvement of TNF- $\alpha$ in the LPS cascade, several lines of evidence suggest that TNF- $\alpha$ can exert its effects through a cascade of cytokine release rather than by a direct stimulation of sensory afferent neurons. Indeed, $\mathrm{TNF}-\alpha$ is the first cytokine released after LPS administration, and it reaches a maximal plasma concentration after $1 \mathrm{~h}$ (48). In fact, TNF- $\alpha$ may produce hyperalgesia by inducing the secondary release of IL-1 $\beta$, because its effect can be blocked by an IL-1 receptor antagonist (42). In carrageenan-evoked somatic hyperalgesia, the same mech- anism has been reported: bradykinin induces the release of TNF- $\alpha$, which in turn stimulates the release of other hyperalgesic cytokines (IL-1 $\beta$, IL-6, and IL-8) responsible for the generation of cyclooxygenase products and sympathomimetic amines (8). In consequence, these two cytokines seem to play a role in LPS-induced visceral hypersensitivity at different levels and in a cascade.

Doxantrazole, a mast cell stabilizer, when injected before LPS, prevents both the early $(3 \mathrm{~h})$ and the late (12 h) phase of LPS-induced rectal allodynia. Consequently, mast cell activation appears to be involved in the cascade of reactions leading to the nociceptive response related to LPS administration. Concerning the early phase $(3 \mathrm{~h})$, a previous report showed that LPS can directly degranulate mast cells with production of cytokines without substantial release of preformed mediators by exocytosis (20). Moreover, other previous studies report the importance of various immune cells, particularly resident macrophages, from the liver in the production of somatic hyperalgesia appearing early within $1 \mathrm{~h}$ after intraperitoneal LPS administration $(43,44)$. Together, these observations permit us to suggest that the early phase could be linked to the activation of immune cells, and particularly mast cells, present in sites other than the gut wall because this early nociceptive response is abolished by previous treatment with a mast cell stabilizer, doxantrazole, and because no immediate mucosal mast cell degranulation is observed histologically in the gut. Concerning the late phase $(12 \mathrm{~h})$, we suggest that this phase is related to the development of an inflammatory reaction triggered by LPS and involving a delayed gut mucosal mast cell degranulation. Indeed, our histological study shows a decrease in mucosal mast cell number occurring $5 \mathrm{~h}$ after LPS administration, and this phase is abolished by doxantrazole. Moreover, this hypothesis is in agreement with a previous study showing that BrX-537A, a potent gut mucosal mast cell degranulator (30), promotes only a delayed rectal allodynia observed from 6 to $12 \mathrm{~h}$ after its administration (3). Furthermore, we have shown here that BrX-537A triggers an immediate $(<1 \mathrm{~h})$ mucosal mast cell degranulation in the gastrointestinal tract. Consequently, we can hypothesize that the late phase of rectal allodynia, consecutive to intraperitoneal LPS administration, is linked to resident mast cell degranulation localized in the intestinal tract.

Vagus nerve serves as an informational highway for inflammatory signals from the periphery, and bilateral truncal vagotomy abolishes a wide range of behavioral and neural effects of peripheral administration of LPS. A part of the "illness" signals elicited by intraperitoneal cytokines or LPS is relayed directly to brain primarily by the vagus nerve, which activates a centrifugal pain facilitatory pathway. Indeed, proinflammatory cytokines (IL-1 $\beta$ and TNF- $\alpha$ ) produce somatic hyperalgesia by activating vagal afferents $(42,44)$. In contrast, our data demonstrate that total subdiaphragmatic vagotomy amplifies LPS-induced rectal allodynia and thus that the vagus nerve has a protective effect 
against LPS-induced visceral allodynia. Chemical, electrical, or physiological activation of cardiopulmonary, diaphragmatic, or subdiaphragmatic vagal afferents can result in either facilitation or inhibition of nociception in some species, depending on the intensity of stimulation (for review, see Ref. 31). For example, high-intensity stimulation of vagal afferents activates spinal descending inhibitory systems, whereas low intensity stimulates pain facilitatory circuits (34). Therefore, it can be postulated that, according to the intensity of the stimulus applied in our study, vagal afferent fibers can participate in a feedback loop directly controlling chemical nociceptive inputs from the periphery by activating descending antinociceptive pathways. However, there is substantial evidence that sensory neurons have a protective role against injury to the gut $(6,33)$. Indeed, worsening of inflammation has been observed in acute colitis models after perivagal capsaicin pretreatment, suggesting a direct protective function of vagal afferents on colonic mucosa against inflammation (23). Thus we can hypothesize that similar processes may underlie the protective action of vagus nerve against local inflammatory reactions resulting from LPS administration. However, it can also be hypothesized that the ability of total subdiaphragmatic vagotomy to reduce LPS hyperalgesia, in some studies, or to amplify the same response, as seen in our data, may be due to differences in the dose of LPS applied. Indeed, the dose of $1 \mathrm{mg} / \mathrm{kg}$ is very high compared with doses used in somatic models $(16,43)$, inducing, in particular, fever and behavioral or locomotive disturbances. In consequence, the vagus nerve appears to possess a powerful role in mediating peripheral immune signals to the brain, but its role must be different according to the nature and/or the amplitude of the aggression and the pathophysiological context developed after LPS infection. It is clear, however, that multiple circuits mediating pain responses exist and are activated under different circumstances.

In summary, the present study indicates for the first time that peripherally injected LPS lowers the visceral pain threshold to rectal distension, this allodynia being observed between 9 and $12 \mathrm{~h}$, and that this effect is mediated by two cytokines, IL- $1 \beta$ and TNF- $\alpha$, and involves mast cell degranulation. Because intraperitoneal administration of LPS is associated with inflammatory reactions in the gut, this result adds some insights into possible mechanisms by which immune reactions of the brain-gut axis may participate in the genesis of visceral allodynia.

We thank C. Betoulieres, L. Ressayre, and I. Lorette for technical assistance and Institut National de la Recherche Agronomique and Solvay-Pharma Laboratories for financial support.

This work was presented in part at the 16th International Symposium on Gastrointestinal Motility, Lorne, Victoria, Australia, February $15-20,1998(3 a)$

\section{REFERENCES}

1. Bergin AJ, Donnelly TC, McKendrick NW, and Read NW. Changes in anorectal function in persistent bowel disturbance following salmonella gastroenteritis. Eur J Gastroenterol Hepatol 5: 617-620, 1993.
2. Cervero F and Laird JMA. Machanisms of touch-evoked pain (allodynia): a new model. Pain 68: 13-23, 1996.

3. Coelho AM, Fioramonti J, and Buéno L. Mast cell degranulation induces delayed rectal allodynia in rats: role of histamine and 5-HT. Dig Dis Sci 43: 727-737, 1998.

3a.Coelho AM, Fioramonti J, and Buéno L. Lipopolysaccharide induces a delayed rectal allodynia via mast cell degranulation in rats (Abstract). Neurogastroenterol Motil 10: 65, 1998.

4. Cunha FQ, Poole S, Lorenzetti BB, and Ferreira SH. The pivotal role of tumor necrosis factor $\alpha$ in the development of inflammatory hyperalgesia. Br J Pharmacol 107: 660-664, 1992.

5. Dray A. Inflammatory mediators of pain. $\mathrm{Br} J$ Anaesth 75 : 125-131, 1995.

6. Evangelista $\mathbf{S}$ and Meli A. Influence of capsaicin-sensitive fibres on experimentally-induced colitis in rats. J Pharm Pharmacol 41: 574-575, 1989.

7. Ferreira SH, Lorenzetti BB, Bristow AF, and Poole S. Interleukin-1 $\beta$ as a potent hyperalgesic agent antagonized by tripeptide analogue. Nature 334: 698-700, 1988.

8. Ferreira SH, Lorenzetti BB, Cunha FQ, and Poole S. Bradykinin release of $\mathrm{TNF}-\alpha$ plays a key role in the development of inflammatory hyperalgesia. Agents Actions 38: C7-C9, 1993.

9. Ferreira SH, Lorenzetti BB, and Poole S. Bradykinin initiates cytokine-mediated inflammatory hyperalgesia. $\mathrm{Br} J$ Pharmacol 110: 1227-1231, 1993.

10. Fukuoka H, Kawatani M, Hisamitsu T, and Takeshige C. Cutaneous hyperalgesia induced by peripheral injection of interleukin-1 $\beta$ in the rat. Brain Res 657: 133-140, 1994.

11. Gracely RH, Lynch SA, and Bennett GJ. Painful neuropathy: altered central processing maintained dynamically by peripheral input. Pain 51: 175-194, 1992.

12. Gué $\mathbf{M}$, Del Rio-Lachèze $\mathbf{C}$, Eutamène $\mathbf{H}$, Theodorou $\mathbf{V}$, Fioramonti J, and Buéno L. Stress-induced visceral hypersensitivity to rectal distension in rats: role of $\mathrm{CRF}$ and mast cells. Neurogastroenterol Motil 9: 271-279, 1997.

13. Handwerker HO and Reeh PW. Pain and inflammation. In: Proceedings of the Sixth World Congress on Pain, edited by Bond MR, Charlton JE, and Woolf CJ. Amsterdam: Elsevier Science, 1991, p. 59-70.

14. Horan MA, Little RA, Rothwell NJ, and Strijbos PJLM. Comparison of the effects of several endotoxin preparations on body temperature and metabolic rate in the rat. Can J Physiol Pharmacol 67: 1011-1014, 1989.

15. Kanaan SA, Saadé NE, Haddad JJ, Abdelnoor AM, Atweh SF, Jabbur SJ, and Safieh-Garabedian B. Endotoxin-induced local inflammation and hyperalgesia in rats and mice: a new model for inflammatory pain. Pain 66: 373-379, 1996.

16. Kent S, Bluthé RM, Kelley KW, and Dantzer R. Sickness behavior as a new target for drug development. Trends Pharmacol Sci 13: 24-28, 1992.

17. Kluger MJ. Fever: role of pyrogens and cryogens. Physiol Rev 71: 93-127, 1991.

18. Layé S, Parnet P, Goujon E, and Dantzer R. Peripheral administration of lipopolysaccharide induces the expression of cytokine transcripts in the brain and in the pituitary of mice. Mol Brain Res 27: 157-162, 1994.

19. Leal-Berumen I, Conlon P, and Marshall JS. IL-6 production by rat peritoneal mast cells is not necessarily preceded by histamine release and can be induced by bacterial lipopolysaccharide. J Immunol 152: 5468-5476, 1994.

20. Ma QP and Woolf CJ. Progressive tactile hypersensitivity: an inflammation-induced incremental increase in the excitability of the spinal cord. Pain 67: 97-106, 1996.

21. Maier SF, Wiertelak EP, Martin D, and Watkins LR. Interleukin-1 mediates the behavioral hyperalgesia produced by lithium chloride and endotoxin. Brain Res 623: 321-324, 1993.

22. Mazelin L, Théodorou V, Moré J, Fioramonti J, and Buéno L. Protective role of vagal afferents in experimentally-induced colitis in rats. J Auton Nerv Syst 73: 38-45, 1998.

23. McLean PG, Picard C, Garcia-Villar R, Moré J, Fioramonti J, and Buéno L. Role of kinin B1 and B2 receptors and mast cells in post intestinal infection-induced hypersensitivity to distension. Neurogastroenterol Motil 10: 499-508, 1998. 
24. McMahon SB, Lewin GR, and Wall PD. Central hyperexcitability triggered by noxious inputs. Curr Opin Neurobiol 3: 602-610, 1993.

25. Million M, Fioramonti J, Zajac JM, and Buéno L. Effects of neuropeptide FF on intestinal motility and temperature changes by endotoxin and platelet-activating factor. Eur $J$ Pharmacol 334: 67-73, 1997.

26. Mohler KM, Torrance DS, Smith CA, Goodwin RG, Stremler KE, Fung VP, Madani H, and Widmer MB. Soluble tumor necrosis factor (TNF) receptors are effective therapeutic agents in lethal endotoxemia and function simultaneously as both TNF carriers and TNF antagonists. J Immunol 151: 1548-1561, 1993.

27. Morrison DC and Rayn JL. Endotoxins and disease mechanisms. Annu Rev Med 38: 417-432, 1987.

28. Morteau O, Hachet T, Caussette M, and Buéno L. Experimental colitis alters visceromotor response to colorectal distension in awake rats. Dig Dis Sci 39: 1239-1248, 1994.

29. Pearce FL, Befus AD, Gauldie J, and Bienenstock J. Mucosal mast cells. II. Effects of anti-allergic compounds on histamine secretion by isolated intestinal mast cells. J Immunol 128: 2481-2486, 1982

30. Randish A and Gebhart GF. Vagal afferent modulation of nociception. Brain Res Rev 17: 77-99, 1992.

31. Reeh PW. Chemical excitation and sensitization of nociceptors. In: Cellular Mechanisms of Sensory Processing, edited by Urban L. Berlin: Springer, 1994, p. 119-270.

32. Reinshagen M, Patel A, Sottili M, Nast C, Davis W, Mueller $\mathbf{K}$, and Eysselein VE. Protective function of extrinsic sensory neurons in acute rabbit experimental colitis. Gastroenterology 106: 1208-1214, 1994.

33. Ren K, Randich A, and Gebhart GF. Vagal afferent modulation of spinal nociceptive transmission in the rat. J Neurophysiol 62: 401-415, 1989.

34. Ritchie J. Pain from distension of the pelvic colon by inflating a balloon in the irritable bowel syndrome. Gut 14: 125-132, 1973.

35. Romanovsky AA, Shido O, Sakurada S, Sugimoto N, and Nagasaka T. Endotoxin shock: thermoregulatory mechanisms. Am J Physiol Regulatory Integrative Comp Physiol 270: R693R703, 1996.

36. Romanovsky AA, Simons CT, Szekely M, and Kulchitsky VA. The vagus nerve in the thermoregulatory response to sys- temic inflammation. Am J Physiol Regulatory Integrative Comp Physiol 273: R407-R413, 1997.

37. Ruckebusch $\mathbf{M}$ and Fioramonti J. Electrical spiking activity and propulsion in small intestine in fed and fasted rats. Gastroenterology 68: 1500-1508, 1975.

38. Safieh-Garabedian B, Kanaan SA, Haddad JJ, Abou Jaoude P, Jabbur SJ, and Saadé NE. Involvement of interleukin-1 $\beta$, nerve growth factor and prostaglandin $\mathrm{E}_{2}$ in endotoxin-induced localized inflammatory hyperalgesia. $\mathrm{Br} J$ Pharmacol 121: 1619-1626, 1997.

39. Safieh-Garabedian B, Poole S, Allchorne A, Winter J, and Woolf CJ. Contribution of interleukin-1 $\beta$ to the inflammationinduced increase in nerve growth factor levels and inflammatory hyperalgesia. $\mathrm{Br} J$ Pharmacol 115: 1265-1275, 1995.

40. Sullivan MA, Cohen S, and Snape WRJ. Colonic myoelectrical activity in irritable-bowel syndrome. Effect of eating and anticholinergics. N Engl J Med 298: 878-883, 1978.

41. Watkins LR, Goehler LE, Relton J, Brewer MT, and Maier SF. Mechanisms of tumor necrosis factor- $\alpha$ (TNF- $\alpha)$ hyperalgesia. Brain Res 692: 244-250, 1995.

42. Watkins LR, Wiertelak EP, Goehler LE, MooneyHeiberger K, Martinez J, Furness L, Smith KP, and Maier SF. Neurocircuitry of illness-induced hyperalgesia. Brain Res 639: 283-299, 1994.

43. Watkins LR, Wiertelak EP, Goehler LE, Smith KP, Martin D, and Maier SF. Characterization of cytokine-induced hyperalgesia. Brain Res 654: 15-26, 1994.

44. Weston AP, Biddle WL, Bhatia PS, and Miner PB. Terminal ileal mucosal mast cells in irritable bowel syndrome. Dig Dis Sci 38: 1590-1595, 1993.

45. Wiertelak EP, Smith KP, Furness L, Mooney-Heiberger K, Mayr T, Maier SF, and Watkins LR. Acute and conditioned hyperalgesic responses to illness. Pain 56: 227-234, 1994.

46. Yirmiya R, Rosen H, Donchin O, and Ovadia H. Behavioral effects of lipopolysaccharide in rats: involvement of endogenous opioids. Brain Res 648: 80-86, 1994

47. Zuckerman SH, Shellhaas J, and Butler LD. Differential regulation of lipopolysaccharide-induced interleukin 1 and tumor necrosis factor synthesis: effects of endogenous and exogenous glucocorticoids and the role of the pituitary-adrenal axis. Eur J Immunol 19: 301-305, 1989. 